Relations industrielles

Industrial Relations

\title{
Juravich, Tom and Kate Bronfenbrenner, Ravenswood: The Steelworkers' Victory and the Revival of American Labor
}

\section{Margaret Hallock}

Volume 55, numéro 4, 2000

URI : https://id.erudit.org/iderudit/051367ar

DOI : https://doi.org/10.7202/051367ar

Aller au sommaire du numéro

Éditeur(s)

Département des relations industrielles de l'Université Laval

ISSN

0034-379X (imprimé)

1703-8138 (numérique)

Découvrir la revue

Citer ce compte rendu

Hallock, M. (2000). Compte rendu de [Juravich, Tom and Kate Bronfenbrenner, Ravenswood: The Steelworkers' Victory and the Revival of American Labor].

Relations industrielles / Industrial Relations, 55(4), 790-793.

https://doi.org/10.7202/051367ar

Tous droits réservés (C Département des relations industrielles de l'Université Laval, 2000
Ce document est protégé par la loi sur le droit d'auteur. L'utilisation des services d'Érudit (y compris la reproduction) est assujettie à sa politique d'utilisation que vous pouvez consulter en ligne.

https://apropos.erudit.org/fr/usagers/politique-dutilisation/ 
la règle, de l'ordre négocié et de la morale.

Cet ouvrage est à la fois sociologique et philosophique. L'auteur, à travers un examen fort érudit de l'expérience humaine en négociation, propose en bout de ligne un ordre toujours négocié, comme garantie de sa stabilité et de son renouvellement : la négociation, inlassablement, crée et détruit des règles.

Ce livre ne veut aucunement enseigner comment négocier. Ce n'est pas à cet égard un livre de recettes comme trop souvent en voit-on, hélas ! Thuderoz s'arrête plutôt à répondre à une question fondamentale : pourquoi négocier autant en contexte d'échange que de détermination de règles.

Il s'agit donc d'un ouvrage d'un niveau d'abstraction plus élevé que ce à quoi nous sommes habituellement confrontés en matière de négociation. Cependant, sans tomber dans le pragmatisme, il faut déplorer ce peu de place que Thuderoz réserve au concept de « pouvoir » dans son étude sur la négociation. Non seulement cette notion de pouvoir de négociation est au cœur même de la nature des échanges inhérents à toute activité de négociation, mais elle dirige également à priori, pour se consolider ou se réhabiliter, les processus pratiques par lesquels la négociation se concrétise, à savoir les structures et les stratégies de négociation. Il s'agit là d'une inévitable trilogie interdépen- dante dont le résultat même de toute négociation dépend. Peut-être faudraitil y revenir.

Un autre reproche, plus de forme, concerne l'organisation de l'ouvrage. Il est rare que, dans un même livre, on retrouve trois « chapitre $1 »$, deux «chapitre 2 » et deux « chapitre 3 » (voir le sommaire). Même l'auteur y perd son latin en se référant, dans la présentation de son ouvrage (p. 44), aux chapitres 2 , $3,4,5,6$ et 7 . On ne retrouve pas les quatre derniers.

Maintenant, les fleurs. Au-delà des reproches ici adressés, cet ouvrage de Thuderoz est d'un français impeccable, à lecture agréable et fluide. Ses nombreuses références et citations démontrent bien qu'il possède son sujet. I1 réussit à rendre son message d'une façon sublime. Ce livre devrait être lu et médité par tous ceux qui s'intéressent à la négociation. Il comble un vide.

Les relations industrielles entendues dans un sens très large sont autant techniques que valeurs. Elles performent relativement bien au niveau des techniques. Elles sont très faibles au niveau des valeurs. Et les relations industrielles exigent la compréhension de ses fondations et de ses sources intellectuelles. C'est dans ce créneau que se situe l'excellente contribution de Christian Thuderoz.

Jean SeXton Université Laval

\section{Ravenswood: The Steelworkers' Victory and the Revival of American Labor by Tom JuRAVICH and Kate BRoNFENBRENNER, Ithaca, N.Y.: ILR Press, 1999, 245 pp., ISBN 0-8014-3633-8 (alk. paper).}

Midway through the twenty-month lockout of workers at the Ravenswood Aluminum Corporation (RAC), one of the woman activists said, "I don't feel like we're fighting for ourselves. I feel like we're fighting this for every working person in America" (p. 131).
Marge Flanigan was right. The heroic battle of the United Steelworkers of America (USWA) at Ravenswood was a turning point in U.S. labour's fightback against decades of corporate union-busting tactics and the impact of economic restructuring. This battle 
demonstrated to members and staff of the USWA and, indeed, to the rest of the labour movement, what it takes to win.

The subtitle of this account, The Steelworkers' Victory and the Revival of American Labor, may seem presumptuous, and history may prove it so. But Tom Juravich and Kate Bronfenbrenner make their case exceedingly well in this informative and engaging review of an emotional, all-out battle against truly maleficent individuals. The book is an achievement, but no less so than the inspiring and dramatic struggle of the 1700 workers and residents of Ravenswood, West Virginia in the early 1990s, who took on "Fort RAC" and won.

They won not only because of their incredible determination and grit, but because the Steelworkers assigned George Becker, now president of USWA, to the lockout when it was months old. He found a unified local union without power and no clue about how to win: "I found our people were sitting on the picket line with no effective means of putting the company under pressure whatsoever... And I found at the time we had about eleven hundred scabs in the plant already... Simply said, nothing was being done that would be effective in pressuring the company to the bargaining table."

What follows is the account of what has come to be known as "strategic" or "coordinated" campaigns, an effort to win by exploiting corporate vulnerabilities, pressuring the company back to the bargaining table with targeted but escalating action and tactics, backed up by prodigious research and the deep involvement of the rank and file.

Ravenswood is a worthy addition to a small but growing literature on corporate or strategic campaigns. Such campaigns are an essential part of labour's toolbox as it rebuilds its power. Without success at the bargaining table, we will not win the battle to organize and represent the millions of unorganized workers. This volume, while focusing on one struggle, has lessons for all of labour on creative new ways to use union strengths to take on the employer and advance the interests of workers and the community.

The context for Ravenswood in 1990 had become all too familiar in the U.S. Unions had fought to obtain pattern bargaining during the postwar period, bargaining with multiple employers simultaneously and successfully to take wages out of competition by setting employment standards in key industries. These patterns were systematically eliminated during the 1980 s in steel, rubber, mining, automobiles and other labour strongholds by a devastating combination of economic restructuring and an explicit corporate strategy of deunionization. The most famous case may be the loss of the air controllers' strike in the mid-1980s, but this was not the first. Systematic deunionization was already underway in electrical manufacturing, coal and mining. During the rest of the $1980 \mathrm{~s}$, the corporate stranglehold on labour law made strikes ineffective or worse, turning them over to employers as their weapon to break the union. Formal charges of labour law violations became "little more than annoying pieces of paper" (p. 69) to corporate leaders determined to pursue a deunionization strategy.

While labour was slow to adapt, there were early signs of strategic campaigns. In Copper Crucible (1995), Jonathan Rosenblum dissects the brave but losing fight of the steelworkers against Phelps Dodge in 1983-86. Ray Rogers waged battles against J.P. Stevens in clothing and Hormel in meatpacking. Others took on Coca-Cola internationally, and farmworkers became justifiably well known for "La Causa," the brilliant campaign led by Cesar Chavez in the vineyards of California. With each campaign, labour learned more about the techniques of "thinking like the boss," "going for the higher vulnerability," "maximizing 
member involvement" and other key principles of strategic campaigns ("Labor's Corporate Campaigns," Labor Research Review, 1993).

Ravenswood opens with a chilling account of bargaining by a corporation intent on breaking the union. Inattention to safety caused three deaths in the summer of 1990. But instead of bargaining over these and other worker concerns, the new owners concentrated on demands for labour flexibility and wage concessions, all the while turning the plant into "Fort RAC" by clearing shrubbery, installing new monitoring devices and a chain-link fence, and even adding a helicopter landing pad. When workers would not be goaded into striking, management locked them out and bused in salaried and replacement workers.

All of this is legal under U.S. labour law, with some exceptions. One of the intricacies of labour law is that lockouts are tainted if the employer refuses to bargain in good faith, and the union's legal strategists nearly overlooked this key issue. One of the many strengths of Ravenswood is its explanation of the intricacies of U.S. labour law and the impact it has on both union and employer strategy.

The international union did not pay much attention to the lockout at first, leaving it to the workers to set up support mechanisms and initiate some creative tactics such as "drive-bys" (conducted by the increasingly militant women's support group) intended to choke traffic around the plant and unnerve those inside. But these were clearly not going to be enough, so when Becker arrived he assembled a talented team of researchers and organizers from the AFL-CIO and the union and launched a multi-faceted campaign to pressure Ravenswood on multiple fronts - in the community, workplace, marketplace and financial world.

The campaign had three main components: a strategy to pressure the end users of RAC aluminum; an international campaign against Marc Rich, a true corporate villain and financier who held the ultimate power over RAC; and a legal and regulatory strategy that focused on labour law violations, environmental degradation and violations of health and safety laws. What set Ravenswood apart from other campaigns, however, was the ongoing and intimate involvement of the workers themselves and the dedication to research. The workers traveled to Europe, "exuding West Virginia from every pore in their bodies," winning allies in the labour movement as well as the more civilized business interests there. In the end, they had to swallow some tough demands from the strapped company, but there is no doubt that they won.

Students of labour can learn much from Juravich and Bronfenbrenner's narrative yet analytical account of the campaign. They show that rank and file participation and strategic leadership are both necessary, but that neither is sufficient by itself. The book offers excellent accounts of bargaining, law and organizing. And the authors ably portray other aspects of strategic campaigns that are often overlooked, such as the need for drama and entertainment. The description of a giant puppet of West Virginia organizer Mother Jones chasing Mark Rich through Europe is priceless, as is the warm portrayal of workers building their own "Fort Unity" in Ravenswood. The workers shine here every bit as much as the capable and courageous staff. The style is journalistic, with references placed unobtrusively at the end, making the book accessible to a wide range of readers.

As we have since learned in other campaigns, there is no single formula which produces victory for labour. Ravenswood was a particular type of struggle, but the principles of following the boss and building power are its enduring lessons. The book closes with a statement by Richard Trumka to the 
workers on the eve of their victory: "Ravenswood is the place where working class people said we're going to push until we push you back across the river. It's a place where workers are putting
Corporate America on notice that they can't rob us of our dignity."

Margaret Hallock

University of Oregon

\section{Le travail sans qualités : les conséquences humaines de la flexibilité par Richard SENNETT, traduit de l'américain par Pierre Emmanuel DAUZAT, Paris : Albin Michel, 2000, 223 p., ISBN 2-226-11501-3.}

Il s'agit de la traduction de l'ouvrage paru en 1998 sous le titre The Corrosion of Character: The Personal Consequences of Work in the New Capitalism, New York : W.W. Norton \& Company.

L'auteur nous fait part de ses constats, observations et réflexions au sujet de certains effets du travail en cette nouvelle économie. À cette fin, le professeur Sennett rappelle le sens étymologique de quelques termes autrefois chéris tels que carrière, caractère, job, etc. pour nous démontrer par la suite comment ils ont perdu leur sens traditionnel. En effet, nous dit-il, comment pouvons-nous faire carrière, soit suivre une voie dans une direction souhaitée, en un monde où seul l'immédiat semble s'imposer. Comment le travailleur peut-il développer et affirmer son caractère alors que les fonctions successives qu'impose la flexibilité le privent de tout repère ? Cette flexibilité, rappelle-t-il, n'a plus le sens qu'on lui donnait, à savoir ployer face à la secousse puis reprendre sa forme originale alors que le travailleur dit "flexible» ploie sous la contrainte et se déplace pour tenter de devenir un automate " polyfonctionnel ».

Il ne s'agit pas d'une étude théorique où l'on construit une savante démonstration à l'aide de quelques modèles et notamment par voie déductive. Le professeur Sennett fait appel à quelques situations bien concrètes et relativement simples pour étayer ses propos. Ainsi, le lecteur peut facilement partager ce discours tellement, sans être aussi un féru de la sociologie du travail, il connaît ou reconnaît lui-même de sem- blables situations de fait qui meublent son voisinage ou qui hantent son esprit. Dès lors, les observations fort perspicaces de l'auteur vont être plus facilement retenues et comprises. Au strict plan pédagogique, une telle approche rend le livre plus accessible à un vaste public.

On ne saurait cependant considérer cet ouvrage comme une simple vulgarisation de l'état du monde du travail sous le soleil néocapitaliste. L'auteur prend habilement à témoin les ouvrages les plus classiques tels que ceux de Virgile, Rousseau, Locke, Smith, Voltaire, Weber, Lippman, etc. De plus, l'ouvrage comprend, en annexes, dix tableaux statistiques susceptibles de mieux illustrer ses thèses.

L'auteur retient particulièrement trois lieux de travail qui connurent des transformations radicales quoique fort différentes les unes des autres. Le premier cas, et sans doute le principal, vise une boulangerie qu'il visita d'abord à l'occasion d'études de terrain en vue de son ouvrage Les tyrannies de l'intimité paru il y a vingt-cinq ans. Cette boulangerie italienne de Boston, où les boulangers étaient grecs, subsiste encore mais comme simple fond de commerce maintenant qu'elle est intégrée par voie d'acquisition à une entreprise d'envergure nationale. Par la magie de l'informatique, on ne goûte plus la pâte, on ne la palpe plus, on ne la sent plus, on ne fait que la regarder in vitro et la manipuler à l'aide des icônes du tableau de bord qui, en fonction du logiciel, normalisent les processus de production (programme SIMS). La chaleur ambiante, la sueur 